\title{
New data on the monitoring of dangerous invasive insect species in Abkhazia
}

\author{
Dbar Roman ${ }^{*}$, Kiriya Mikhail ${ }^{* *}$, Romanova Natali*** \\ Institute of Ecology of the Academy of Sciences of Abkhazia
}

\begin{abstract}
The article presents the monitoring data of the three most dangerous invasive insect species in the territory of Abkhazia: palm borer Paysandisia archon (Burmeister), boxwood moth Cydalima perspectalis (Walker), red palm weevil Rhynchophorus ferrugineus (Olivier). All of them penetrated into Abkhazia in the period from 2014 to 2016 from the Russian Federation. The penetration of invasive species is accompanied by serious ecological and economic consequences. Pest populations show resilience and expansion of forage plant infestation zones. To control pest populations, regular pesticide treatments are required for Buxus colchica boxwood stands, as well as for all types of trees used in the green architecture of Abkhazian cities.
\end{abstract}

\section{Relevance}

The last decade is characterized by the appearance of a number of invasive species, many of which proved to be extremely aggressive pests of various ornamental, agricultural and forest crops with serious ecological and economic losses. In this regard, monitoring of the state of populations of these insects becomes particularly important and serves as a basis for the development of strategies to control them.

Uruguayan palm moth Paysandisia archon (Burmeister), boxwood moth Cydalima perspectalis (Walker), red palm weevil Rhynchophorus ferrugineus (Olivier) are among the most aggressive species that penetrated into Abkhazia in recent years and to which this article is devoted.

Invasive insects were monitored using different techniques depending on the peculiarities of the biology of these insects. We used visual monitoring methods, route surveys, pheromone and glue traps.

\section{Palm Moth - Paysandisia archon}

The South American palm borer Paysandisia archon was first discovered in Abkhazia in 2016. It entered the country from the border town of Sochi, where it was first observed in 2014. [1]. Invasion is caused by the import of infected palm trees for landscaping of the city.

Palm borer Paysandisia archon develops in one generation per year in the natural and climatic conditions of Abkhazia. The life span of a butterfly is 2-4 weeks.
The female lays eggs in groups (about 150 eggs) on palm fibers, usually closer to the top of the crown. The incubation period lasts 1-3 weeks.

The caterpillar goes through 9 ages during its development. The development of the palm driller caterpillar lasts 7-10 months. The caterpillars hatched from the eggs drill into the trunk, where they begin to feed on wood, completely destroying the growth point of the palm tree.

The pupal stage lasts from 6 to 10 weeks. [1]

\section{Monitoring data}

The spread of the palm borer Paysandisia archon over the territory of Abkhazia has a non-linear character. Thus, initially the palm moth was detected once on hemp palm (Trachycarpus) in Tsandrypsh village within $2 \mathrm{~km}$ from the state border with the Russian Federation along the Psou River.

However, in other areas it could only be found in 2018. Only in the period from July to August 2018, the first signs of damage to Trachycarpus fortunei palms by this pest were detected in different points of the city of Sukhum. During the entire warm period of 2018, from July to November, new foci of palm moth spread were found throughout the city.

In 2019, the zone of infestation of hemp palm trees expanded, and the number of plants affected by the pest in Sukhum was more than $80 \%$.

In addition, sporadic deaths of palms of the genera Washingtonia and Sabal were reported. Among big genera palm species, Phoenix canariensis was the most affected one. Perforated and deformed leaves were observed on this palm, and caterpillars of palm moths of various ages were found on the trunks.

In 2019, route surveys of park zones in all cities and districts of Abkhazia were carried out, the results

${ }^{*}$ Corresponding author: romandbar@mail.ru

** Corresponding author: m.kiriya@yandex.ru

*** Corresponding author: romanovan99@mail.ru 
of which showed the outbreak nature of the infestation of the palm moth. From peculiarities of biology of this species and its inability to move more than 20-25 km on its own, we may assume that the spread of the pest in Sukhum has anthropogenic character, because outside of it it was detected only once in Gagra and in the above-mentioned settlement Tsandrypsh in $100 \mathrm{~km}$ from the capital.

In 2020, repeated route surveys of palm plantations in the districts of the Republic of Abkhazia were carried out. The pest was detected once in the town of Novy Afon, probably already a reverse infestation from the city of Sukhum. In 2021 the pest was also detected in Pitsunda. During the whole period of monitoring the palm moth was most widespread only in Sukhum, and in most cases the forage plants were hemp palm Trachycarpus fortunei and Chamaerops humilis. This circumstance is linked with the fact that in and around Sukhum the highest number of this palm trees often grows in many places as a self-seeding weed.

The general vector of Sochi-Sukhum invasion cannot be considered objective due to much later detection of damaged plants all along this route. The main factor in the spread of this invasive species is anthropogenic, namely infested planting material.

Lacking the pheromones for palm moth monitoring, we attempted to use female moths placed in traps as bait in order to attract males, but this method was not effective.

In the conditions of Abkhazia, mass flight of moths is observed in the period from May to July. Monitoring data showed that the number of palm moths is not decreasing, and the affected area covers almost the entire area of Chinese palm growth in the republic. Since it is not planned to include Chinese fan palm in the system of protection and preventive treatments with insecticides, and given that it has no natural enemies, it will continue to spread and in 3-4 years it will leave the city parks and squares without hemp palm (Trachycarpus).

\section{Red palm weevil Rhynchophorus ferrugineus (Olivier)}

The red palm weevil Rhynchophorus ferrugineus is a highly aggressive pest of palm trees. It feeds on practically all palm species, but it mainly feeds on Phoenix canariensis.

For the first time this pest was detected in Abkhazia in October 2016 in the border village of Tsandrypsh on several specimens of the date canary, which suffered from the activity of larvae of the palm weevil.

The palm weevil develops one generation per year. The female is capable of laying 150-350 eggs on top of palms as close to the growing point as possible. The egg phase is about 7 days.

The hatching larvae penetrate inside the palm tree, drilling through the trunk and feeding on plant tissues, destroying the core and destroying the growing point. The larval stage lasts for 3 - 4 months.
The palm weevil develops one generation per year. The female is capable of laying 150-350 eggs on top of palms as close to the growing point as possible. The egg phase is about 7 days.

The hatching larvae penetrate inside the palm tree, drilling through the trunk and feeding on plant tissues, destroying the core and destroying the growing point. The larval stage lasts 3 to 4 months.

The larvae form an oval cocoon of palm fronds before pupating. The pupal stage lasts 14-21 days.

The total life cycle is about 4-5 months, but the palm weevil is able to diapause at almost all life cycle stages. [2]

A biological feature of the weevil is that after the adults emerge from the pupa, they do not all disperse, but may remain on the food plant and mate and lay eggs there. This strategy leads to a multiple increase in the number of weevil larvae on one tree and its rapid death.

\section{Monitoring data}

The penetration of the red palm weevil as well as the palm moth into Abkhazia became possible after the accumulation of this pest in the territory of Sochi, due to large-scale landscaping projects and importation of infected planting material from Southern Europe [2].

The red palm weevil is even more limited in its independent movement. According to various estimates, the total flight length. However, in reality, it is capable of covering a distance of up to $1.5 \mathrm{~km}$ on its own.

During the monitoring period of 2016-2018, the palm weevil spread over Tsandrypsh settlement and completely invaded almost all parks and green areas of resort facilities up to Bagrypsta settlement. From the first detection and until 2018, the pest spread zone was limited to this settlement. Monitoring using pheromone traps was conducted on a weekly basis from February to June 2018. During this period, traps recorded 5-7 pest adults per hectare, which is classified as a significant presence of the pest.

Further spread of the weevil along the Black Sea coast of Abkhazia was restrained by a buffer zone of more than $10 \mathrm{~km}$ wide with no forage plants. However, in August 2018 as a result of monitoring surveys, infested trees of Phoenix canariensis were found in different parks of Gagra city.

In addition, during the same period, infested trees were found in Sukhum city. The first foci of the pest spread did not exceed within a radius of $1.5 \mathrm{~km}$.

Monitoring traps were installed throughout Sukhum in August-September 2018, evenly covering the pest spread area. During the whole warm period until November, pest adults have been detected in pheromone traps. The average value per trap was 12 adults per week per hectare.

Considering the focal nature of the spread, it was decided to make a complete survey and inventory of all the palm trees in Abkhazia with GPS localization of infested palms. 
During route surveys and visual monitoring on the territory of Abkhazia three pest outbreaks were identified: Tsandrypsh village and Bagrypsta village (independent vector of infestation from the border territory) and in the parks of Gagra. Mixed type of infestation has been detected here: natural, anthropogenic with planting material, with automobile transport from old pest outbreaks. In Sukhum city the main factor of infestation was planting material used in landscaping of city parks.

During 2019-2021, total treatments of big palms were carried out in Sukhum City using imidaclopridbased systemic insecticides. At the same time, monitoring was conducted with the use of pheromone traps. The trap network was expanded to cover an area of more than 20 hectares, including all green areas of Sukhum. The trap network was extended to cover an area of 20 hectares, including all green areas of Sukhum city.

Weekly monitoring showed a significant infestation and distribution of the pest in Sukhum (more than 20 adults per week). Eighteen dead date palm trees were cut down. Damage to other palm varieties by the Red Palm Weevil was not detected which allows us to conclude that date canary is the most preferred food plant for this pest.

During the whole year of 2020, up to 30 imago palm weevils were detected in pheromone traps in Sukhum, while from May to August 2021 only 7 imago were detected. These data indicate the effectiveness of the pesticide treatment program for large palm trees in the metropolitan area.

In 2020, large-scale surveys were conducted, which included all the major park areas of Abkhazia. At the same time, isolated damaged trees were found in the cities of Pitsunda and New Athos. In both cases, the factor of anthropogenic import of the pest from the nearby cities of Sukhum and Gagra is possible and most understandable.

Monitoring conducted in Gagra with the use of pheromone traps also showed a high number of pests in the city. In 2020, the monitoring network consisted of more than 50 traps located throughout the city in places where palm trees grow. Weekly data ranged from 150200 imagos.

Such high figures are explained by insufficient and very limited activities by the authorities and relevant services, the late removal of dead trees, the lack of preventive treatments of palm trees in the parks and green areas of Gagra with the use of systemic insecticide. During the entire one-year monitoring period of 2020, almost 1,700 imagos were collected in traps in Gagra.

After such a high pest population in Gagra, largescale chemical treatments were carried out and all the dead Canary palm trees were removed. As a result, the monitoring data of 2021 showed the effectiveness of the work carried out.

For the current year, the monitoring data presented no more than 400 adults with an average weekly count of 34 adults.
In 2021, the monitoring network was expanded to 20 traps in Pitsunda and 50 traps in Gagra. Pheromone trap data for Pitsunda showed insignificant focal presence of the pest. Thus, during the weekly monitoring period from May to August, 28 adults were detected, with an average of 2-3 adults per week.

Pheromone traps for red palm weevil have shown to be highly effective for determining the extent of pest infestation in urban parks and for taking measures for chemical control of the pest (Fig.1). Proceed from the activities carried out in Sukhum city it became obvious that the combination of monitoring methods with timely chemical treatment as well as removal of dead trees, which serve as breeding grounds for the pest, showed their effectiveness. This allows us to talk about the development of a strategy in solving this problem, since several different services and departments, a research institute, as well as volunteers are involved in this work.

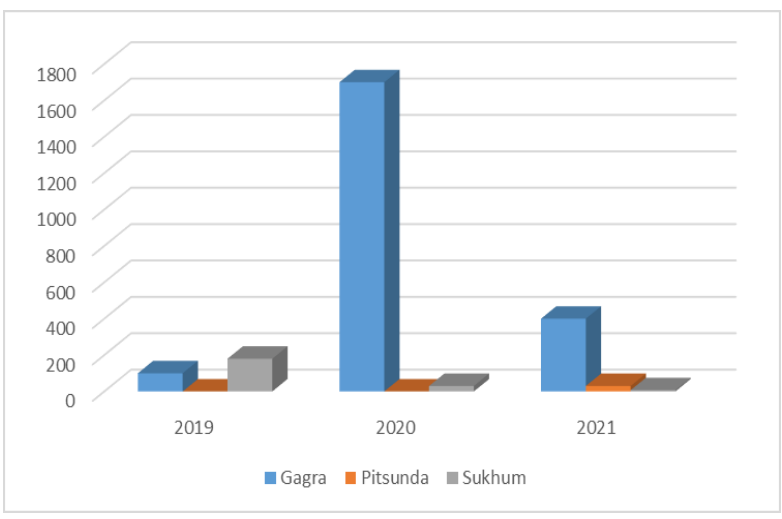

Fig.1. Dynamics of registering adults of red palm weevil in traps

\section{Boxwood moth Cydalima perspectalis (Walker)}

The boxwood moth Cydalima perspectalis entered the territory of the Republic of Abkhazia in 2013 from the border town of Sochi, where the pest was brought with Italian planting material - evergreen boxwood Buxus sempervirens, intended for landscaping of Olympic facilities in 2012. Under natural conditions, the boxwood inhabits the territory of China and the Far East.

In natural conditions of Abkhazia the boxwood moth develops in three, and under favorable conditions in four generations per year.

Females lay eggs in small groups, mainly on the underside of leaves. Total fecundity of one female on average exceeds 200 eggs.

The emerged greenish-yellow larvae are about 1-2 mm long. It takes 3 to 4 weeks for larvae to develop. Adult caterpillars are about $4 \mathrm{~cm}$ long. Lacking feeding on green mass in a tree crown, older caterpillars are capable of feeding on boxwood bark; younger caterpillars may join feeding on soft layers of bark after larger caterpillars open tree bark with their strong jaws. 
Pupa, 25-30 mm long, is located in a cocoon between boxwood leaves, bound by cobwebs. Under favorable conditions, a flight of butterflies is observed in 10-15 days. [3]

\section{Monitoring data}

After a large-scale invasion of boxwood firewood in the period from 2014 to 2016, almost all natural boxwood forests were destroyed. The penetration of this invasive species into the Caucasus has led to one of the largest environmental disasters of our time. The forests of the Colchian boxwood Buxus colchica were almost completely destroyed in the entire area of their growth in the Colchian botanical and geographical province.

In Abkhazia, only some areas remained in the Bzyb River basin, where it was possible to preserve narrow strips of natural boxwood plantations by chemical treatments of roadside spaces.

The absence of natural enemies of boxwood moth, as well as the rapid increase in the number and overeating not only the green mass, but also the bark of boxwood trees led to the rapid death of almost the entire population of this relic of the tertiary flora of Abkhazia.

The total area of boxwood forests before the invasion of boxwood moth was estimated at about 200 thousand hectares. To date, boxwood is preserved in a narrow strip along the highway in the Bzyb Gorge and in the Ritsa National Park and in the vicinity of the Gega Waterfall.In addition, during the route trips in the places of former boxwood growth, we observe everywhere the sprouting of seed material, accumulated in the last years of fruiting boxwood forests. However, adult trees are destroyed almost completely, in rare cases, small vegetative shoots can be observed. Sprouts of boxwood from a stock of seeds resting in the ground were noted in many places of past growth, but they too are at risk of being destroyed by the present population of boxwood moth.

In 2020, monitoring pheromone traps were installed in areas of former boxwood forests to monitor the status of boxwood moth population. Thus, there were selected sites in the Bzyb Gorge, near the Gega waterfall, the Skurcha Reserve, the Kodori Gorge, and the vicinity of the Shakuran waterfall (Fig. 2).

More than 40 pheromone traps were installed. As a result of the monitoring, maps of the presence and the spread of boxwood moth were created. During this monitoring period, traps were checked for the presence of the pest in accordance with a weekly schedule from July to October. These data were used for planning boxwood treatment and making prognoses for the following seasons.

However, during the entire period of observations in 2020, only 3 adults of boxwood moth were captured in the traps. These data indicated an extremely depressed state of the boxwood moth population due to a sharp reduction of the food base. The depressive state of the population is evidenced by the presence of individuals with a wingspan of $14-18 \mathrm{~mm}$, which is more than two times less than the usual size of adults of boxwood flaxwing. Based on these data the total number of chemical treatments in the Bzyb Gorge was reduced to 2 per season, while in the early years of infestation treatments were carried out 4-6 times.

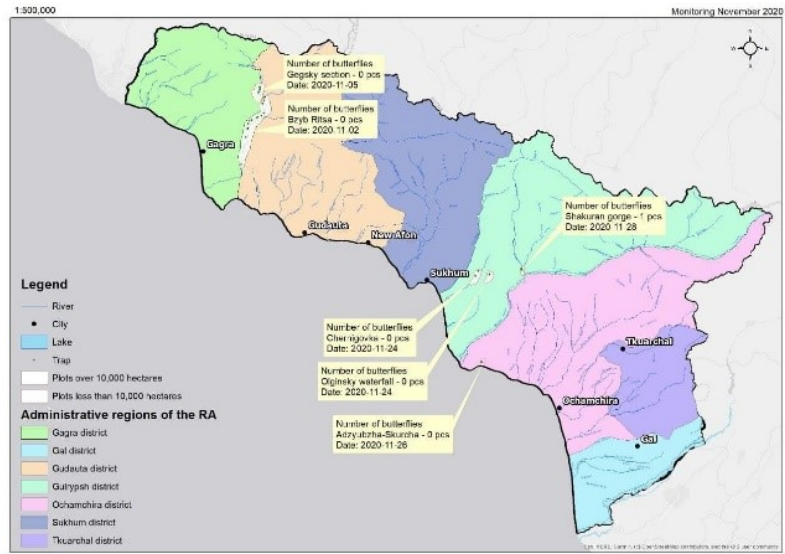

Fig.2. Monitoring map of boxwood moth in 2020

It is noteworthy that 1 specimen of the boxwood moth was found in the Shakuran River Gorge, where no adult live trees of boxwood remained and most likely it was able to complete its development cycle on small scattered sprouts of boxwood and additional feeding on other plant species. Such facts were repeatedly noted during earlier route observations. The eaten leaves of the boxwood, which are not characteristic for the feeding of boxwood caterpillars, were observed in Paliurus spina-christi and Ruscus aculeatus pontica.

In 2020 two more cases of the boxwood moths presence in the region were observed in the Bzyb Gorge area.

During the entire monitoring period from May to October, no cases of mass formation of caterpillars were recorded, and there was also no flight of boxwood moth.

In June 2021, in accordance with the monitoring plan for boxwood moth, 28 traps were installed in the gorges of the Gega, Yupshara, and Bzyb rivers.

The results of the monitoring were quite unexpected (Fig. 3). During the first inspection of the pheromone traps 86 adult pests were found. Probably, the sharp increase in the number of the pest and the observed dynamics in 2021 are due to the reduction of pesticide treatments of the remaining boxwood trees in these gorges last year. Taking into account biological features of the species, fixation of such a number of moths by traps in the area of the Gega waterfall and in the gorges of Yupshara and Gega rivers, indicates mass flight before the processes of mating and egg laying. Monitoring data indicate the need for further study of the state of the pest population under conditions of almost complete elimination of the forage plant. 
with the need to continue chemical treatments in places where it still remains.

\section{References}

1. E.N. Zhuravleva, N.N. Karpun, First report on the appearance of a dangerous phytophage of palms (Sochi, 2014).

2. E.N. Zhuravleva, N.N. Karpun, A new dangerous pest of palm trees in Sochi - red palm weevil (Sochi, 2014).

3. N.N. Karpun, V.L. Ponomarev, A. E. Nesterenkova, V.E. Zakharchenko, Phytosan. plant. Quarant. 5052. (2019).

\section{Conclusion}

New monitoring data on populations of the Uruguayan palm moth Paysandisia archon, the boxwood moth Cydalima perspectalis, and the red palm weevil Rhynchophorus ferrugineus showed that they all maintain their aggressiveness and represent an increasing threat to forage plants. In regard to the red palm weevil Rhynchophorus ferrugineus, its numbers are reduced only in isolated areas as a result of chemical treatments, but at the same time the pest spreading range extends to new plantations and areas. Therefore, it is necessary to treat all the big palm trees in the country and to apply pesticides not only to infested palms but also to all the stands for preventive purposes. As for the Uruguayan palm moth Paysandisia archon its population is the most threatening since no methods of chemical suppression are used against it and its numbers are steadily increasing and in the near future as its numbers accumulate it will move from its main forage plant to other palm varieties.

The boxwood moth Cydalima perspectalis after almost complete elimination of its forage plant continues to maintain a small, but apparently stable population which is preserved in the remaining natural and artificial park areas of boxwood in Abkhazia. At the same time, this population of boxwood moth threatens the regeneration of boxwood in the forests of Abkhazia. The further preservation of boxwood in Abkhazia in the near foreseeable future is associated 